\title{
Isolation of Thermotolerant Yeast Strains for Ethanol Production: A Need for New Approaches
}

\author{
Thomas P West* and Daniel E Kennedy II \\ Department of Biology and Microbiology, South Dakota State University, Brookings, SD 57007, USA
}

\begin{abstract}
There is a need for new approaches to isolate thermotolerant yeast strains that can be utilized for the efficient production of ethanol. The simultaneous saccharification and fermentation of starch or lignocellulosic will greatly benefit from thermotolerant yeast strains that actively ferment ethanol at temperatures above $40^{\circ} \mathrm{C}$. The development of new procedures targeting the cell membrane to increase thermotolerance in yeast strains represents an opportunity to advance the ethanol industry.
\end{abstract}

Keywords: Thermotolerant; Ethanol production; Mutant isolation; Yeast

\section{Editorial}

Although ethanol production currently accounts for billions of liters of ethanol produced annually from sugarcane or corn, the utilization of thermotolerant yeast strains could improve the efficiency of ethanol production by allowing fermentation to occur at temperatures greater than $40^{\circ} \mathrm{C}$ [1-3]. With simultaneous saccharification and fermentation of starch or lignocellulosic biomass likely being used to produce ethanol in the future due to its increased productivity at elevated operation temperatures, the isolation of thermotolerant, ethanol-producing yeast strains will be required to ensure that ethanol fermentation occurs. Therefore, the development of novel approaches to isolate thermotolerant yeast strains will be necessary. Prior studies have shown that stress conditions will allow the induction of thermotolerance in the yeast Saccharomyces cerevisiae but if the stress conditions are removed the thermotolerance can be lost $[4,5]$. In a recent investigation, it was shown that thermotolerant $S$. cerevisiae strains isolated by adaptive laboratory evolution to temperatures at $40^{\circ} \mathrm{C}$ or above had a modification in sterol composition [1]. It was hypothesized that the alteration in sterol composition of these adapted strains resulted in their cell membranes exhibiting optimum fluidity and their increased thermotolerance [1]. An earlier study found that changes in the fluidity of the S. cerevisiae cell membrane at high temperatures caused decreased fermentation ability [4]. It may be possible to isolate $S$. cerevisiae mutant strains that are resistant to inhibitors of sterol metabolism or compounds that are known to affect the composition of the cell membrane. It would seem likely that such procedures should allow the isolation of thermotolerant S. cerevisiae mutant strains. Another approach relative to thermotolerant ethanolproducing yeast strains would be to examine resistance to the glucose analogue 2-deoxy-D-glucose. Mutant strains of S. cerevisiae resistant to 2-deoxy-D-glucose were shown to have an increased ability to ferment [6]. The increase in ethanol production by the S. cerevisiae mutant strains was attributed to a lack of catabolite repression by glucose and increased glucose uptake [7,8]. It has been demonstrated that ethanol production by a 2-deoxy-D-glucose-resistant mutant of the yeast Candida molischiana was capable of producing ethanol at $45^{\circ} \mathrm{C}$ unlike its parent strain [9]. The isolation of the majority of S. cerevisiae thermotolerant mutant strains reported in the literature have involved "brute force" screening of mutagenized yeast cells, acclimatization treatment of yeast cells or by screening the cells for their ability to grow on a growth-limiting substrate [10-13].
Clearly, the literature exploring methodologies that allow the isolation of stable, thermotolerant mutant strains from ethanolproducing yeast species is limited and further research is needed. The opportunity exists to use such thermotolerant yeast mutant strains to improve the efficiency of ethanol production which should help reduce the current reliance on petroleum-based fuel. To take advantage of this opportunity, new approaches in the isolation of stable thermotolerant yeast mutant strains capable of being used during high temperature ethanol production will need to be developed.

\section{References}

1. Caspeta L, Chen Y, Ghiaci P, Feizi A, Buskov S, et al. (2014) Biofuels. Altered sterol composition renders yeast thermotolerant. Science 346: 75-78.

2. Abreu-Cavalheiro A, Monteiro G (2014) Solving ethanol production problems with genetically modified yeast strains. Braz J Microbiol 44: 665-671.

3. Koçar G, Civas C (2013) An overview of biofuels from energy crops: Current status and future prospects. Renew Sust Energ Rev 28: 900-916.

4. Suutari M, Liukkonen K, Laakso S (1990) Temperature adaptation in yeasts: the role of fatty acids. J Gen Microbiol 136: 1469-1474.

5. Piper PW (1993) Molecular events associated with acquisition of heat tolerance by the yeast Saccharomyces cerevisiae. FEMS Microbiol Rev 11: 339-355.

6. Rincón AM, Codón AC, Castrejón F, Benítez T (2001) Improved properties of baker's yeast mutants resistant to 2-deoxy-D-glucose. Appl Environ Microbiol 67: 4279-4285

7. D'Amore T (1982) Cambridge prize lecture: Improving yeast fermentation performance. J Inst Brew 98: 375-382.

8. Novak S, D'Amore T, Russell I, Stewart GG (1991) Sugar uptake in a 2-deoxy$\mathrm{D}$-glucose resistant mutant of Saccharomyces cerevisiae. J Ind Microbiol 7 : 35-39.

9. Geiger MR, Gibbons WR, West TP (2014) A thermostable Candida molischiana mutant capable of ethanol production at elevated temperatures. J Pure Appl Microbiol 8: 1743-1748.

*Corresponding author: T. P. West, Department of Biology and Microbiology, South Dakota State University, Box 2104A, Brookings, SD 57007, USA, Tel: (605) 688-5469; Fax: 605-688-6677; E-mail: Thomas.West@sdstate.edu

Received October 23, 2014; Accepted October 24, 2014; Published October 31 2014

Citation: West TP, Kennedy II DE (2014) Isolation of Thermotolerant Yeast Strains for Ethanol Production: A Need for New Approaches. J Microb Biochem Technol 6 : e120. doi:10.4172/1948-5948.1000e120

Copyright: $\odot 2014$ West TP, et al. This is an open-access article distributed under the terms of the Creative Commons Attribution License, which permits unrestricted use, distribution, and reproduction in any medium, provided the original author and source are credited 
Citation: West TP, Kennedy II DE (2014) Isolation of Thermotolerant Yeast Strains for Ethanol Production: A Need for New Approaches. J Microb Biochem Technol 6: e120. doi:10.4172/1948-5948.1000e120

Page 2 of 2

10. Rajoka MI, Ferhan M, Khalid AM (2005) Kinetics and thermodynamics of ethanol production by a thermotolerant mutant of Saccharomyces cerevisiae in a microprocessor-controlled bioreactor. Lett Appl Microbiol 40: 316-321.

11. Jin C, Han N, Wu X, Pan J, Zeng Y. Zhu, M (2005) Isolation and characterization of a highly thermotolerant mutant of Saccharomyces cerevisiae. Ann Microbiol 55: $57-61$.
12. Edgardo A, Carolina P, Manuela R, Juanita F, Jaimea B (2008) Selection of thermotolerant yeast strains Saccharomyces cerevisiae for bioethanol production. Enzyme Microb Technol 43: 120-123.

13. Favaro L, Basaglia M, Trento A, Van Rensburg E, García-Aparicio M, et al. (2013) Exploring grape marc as trove for new thermotolerant and inhibitortolerant Saccharomyces cerevisiae strains for second-generation bioethanol production. Biotechnol Biofuels 6: 168. 